\title{
EFFECT OF TIME OF GESTATION ON FATTY ACID TRANSPORTERS MRNA EXPRESSION IN BOVINE PLACENTA
}

\author{
EFEITO DO TEMPO DE GESTAÇÃO EM EXPRESSÃO DE ARNM DE \\ TRANSPORTADORES DE ÁCIDOS GRAXOS MRNA EM PLACENTA BOVINOS
}

\section{Ramiro DESANTADINA ${ }^{1}$; Silvina QUINTANA ${ }^{2-3}$; Mariana Inés RECAVARREN ${ }^{2}$; Alejandro Enrique RELLING}

1. Instituto de genética Veterinaria, Concejo Nacional de Ciencia y Técnica y Universidad Nacional de La Plata. La Plata, Buenos Aires, Argentina; 2. Laboratorio Bioquímico Fares Taie. Mar del Plata, Buenos Aires, Argentina; 3- Consejo Nacional de Investigaciones Científicas y Técnicas (CONICET), Rivadavia 1917, C1033AAJ Buenos Aires, Argentina; 4. Instituto de Genética Veterinaria, Concejo Nacional de Ciencia y Técnica y Universidad Nacional de La Plata. La Plata, Buenos Aires, Argentina. Currently at: Department of Animal Sciences, The Ohio State University, Ohio. USA. relling.1@ osu.edu

\begin{abstract}
The objective of the study was to evaluate the effect of time of gestation on fatty acid transporter mRNA expression in maternal and fetal bovine placenta. Placentas from twelve cows at different thirds of gestation ( $\mathrm{n}=4$ per third) were sampled at slaughter to measure FATP-1, FATP-4, FABP-1 mRNA concentration in maternal (caruncles) and fetal (cotyledons) side. Once the placenta was removed, $1 \mathrm{~cm}^{2}$ was dissected and, divided into caruncles and cotyledons, stored in sterile tubes, dropped into liquid nitrogen and kept at $-80^{\circ} \mathrm{C}$ until $\mathrm{rtPCR}$ analysis. Data were analyzed as a complete randomized design with a $3 \times 2$ factorial arrangement, using the mixed procedure (SAS 9.3) with repeated measurements on space. Time of gestation, side of the placenta and their interaction were fixed factors, whereas animal was a random factor. There was a time by treatment interaction $(\mathrm{P}<0.01)$ on FATP-1 mRNA expression due to a greater mRNA expression in cotyledons on the first third of gestation as compared with the concentration in caruncles. On the second and third stages of gestation, the mRNA concentration in cotyledons decreased, reaching a similar concentration to that observed in caruncles. Fatty acid transport protein -4 and FABP-1 mRNA concentration were not different $(\mathrm{P}>0.1)$. We conclude that FATP-1 might play an important role in fatty acid transport during early fetal development.
\end{abstract}

KEYWORDS: Fatty acid binding protein. Fetal programming. Fatty acids.

\section{INTRODUCTION}

The n-6 and n-3 fatty acids (FA) are essential, therefore cannot be formed de novo by mammalian cells. Bell (1995) reports that there is little FA passage on bovine placenta. However, all n- 6 and n-3 accumulated on the fetus must be derived from the mother by placenta transfer (INNIS, 2005).

The mechanisms for FA transport across the placenta involve several trans-membrane and intracellular proteins (CAMPBELL et al., 1996). The distribution on different tissues, specificity, and functions are known in non-ruminant species (NICKERSON et al., 2009) and sheep (ZHU et al., 2010); however, it is not known how the gene expression of these proteins change during the length of gestation. Also, there are no studies that show their presence on bovine placenta and if they change their expression throughout the gestation.

Therefore the objective of this study was to evaluate the presence and amount of mRNA coding for fatty acids transport proteins 1 and 4 , FATP-1, FATP-4, (SLC27A1 and SLC27A4, respectively) and fatty acid binding protein 1 (FABP-1) in the fetal and maternal side of the placenta during the different thirds of gestation.

\section{MATERIAL AND METHODS}

FATP-1, FATP-4, and FABP-1 mRNA expression was measured on maternal and fetal size of bovine placenta. The experiment was a complete randomize designed with a 3 by 2 factorial arrangements of the treatments. The main factors were stages in gestation (first, second or third) and the side of the placenta (maternal- caruncle or fetalcotyledon).

Placenta tissue was collected from a commercial slaughterhouse within 30 minutes of the slaughter. Cull cows coming from pasture systems were slaughter following the National Service of Agrofood Health and Quality (SENASA, Argentina) regulations. Based on the size of the placentome (combination of cotyledon and caruncle) and length of fetus (Table 1, modified from ZEMJANIS, 1970) the gestation was divided in three thirds $(n=3$ per third of gestation). From the placentome, a sample an area of $1 \mathrm{~cm}^{2}$ was taken with a sterile scalpel blade. From that sample the caruncule was separated 
from the cotyledon and each subsample was added in a labeled sterile tube and flash frozen using liquid
$\mathrm{N}_{2}$. Samples were store at $-80^{\circ} \mathrm{C}$ until analysis.

Table 1. Characteristics of fetus and bovine placenta according to the month of gestation. Modified from Zemjanis, 1970.

\begin{tabular}{|c|c|c|}
\hline Time of gestation & Fetal characteristics & Placentome size \\
\hline 2-3 months & $10-15 \mathrm{~cm}$. length & Up to $1.5 \times 1 \mathrm{~cm}$ \\
\hline 4 to 6 months & 20 to $55 \mathrm{~cm}$ length & $\begin{array}{l}\text { From } 2 \times 1,25 \mathrm{~cm} \text { (day } 100 \text { ) to } 4 \times 2.5 \mathrm{~cm} \\
\text { (day 180) }\end{array}$ \\
\hline 7 to 9 months & $\begin{array}{l}60 \text { to } 80 \mathrm{~cm} \text { length, } \\
\text { Hairs in the tail (day } 210 \text { ), ears } \\
\text { (day 240) or covering the } \\
\text { whole body (day 280) }\end{array}$ & $\begin{array}{l}\text { From } 5 \times 3 \mathrm{~cm} \text { (day 210) to } 8 \times 5 \mathrm{~cm} \text { (day } \\
\text { 280) }\end{array}$ \\
\hline
\end{tabular}

Total RNA was isolated using the TRIzol® reagent (Invitrogen-Life Technologies, Carlsbad, USA) according to the manufacturer's protocol. RNA preparations were further treated with DNase (Qiagen, Hilden, Germany). Quantity and quality of RNA was measured using UV spectroscopy (Nanodrop Technologies). Complementary DNA (cDNA) was synthesized using a reaction mixture containing $1,5 \mu \mathrm{g}$ of total RNA, random hexamers and the MMLV-reverse transcriptase (InvitrogenLife Technologies), following the procedure suggested by the manufacturer. Negative controls omitting the RNA or the reverse transcriptase were included and tested in the PCR procedure. Complementary DNA of the fetal and maternal placenta were subjected to qPCR assays using Eva Green as intercalating dye (KAPA FAST, Biosystems, Woburn, USA). Quantitative PCR was performed in a Rotor Gene Q thermocycler (Qiagen). The cycling program consisted of an initial denaturation of 2 minutes at $95^{\circ} \mathrm{C}$, and 45 cycles of 15 seconds at $94^{\circ} \mathrm{C}$, specific annealing temperature 20 seconds and $72^{\circ} \mathrm{C}$. After amplification, a melting curve analysis was performed, which resulted in single product-specific melting curve. In all cases, experiments were done in duplicates.

Negative controls for cDNA synthesis and PCR procedures were included in all cases. A list of the primers used in PCR protocols, specific annealing temperature and product length in each case is shown in Table 2. All primers used in this study were designed with Primer Premier Software (PREMIER Biosoft International, Palo Alto, USA).

Relative expression values were calculated by the ddCT method (LIVAK; SCHMITTGEN, 2001). Each of the three targets were analyzed separately, and normalized to bovine beta-actin (ACTB).
Quantification of mRNA levels of FATP1, FATP-4 and FABP-1 was performed on fetal and maternal placenta. The amplification efficiency was determined for each gene using 10-fold dilutions of cDNA. In all assays, standard curves for each gene had a slope between -3.2 and -3.5 and the standard deviation between duplicates was in all cases $<0.167$ as recommended for qPCR (BUSTIN, 2002).

FABP-4 mRNA expression was evaluated using two different sets of primers (Table 2). However, FABP-4 mRNA was not detected using the described primers and conditions.

Data was analyzed as a complete randomized design with repeated measurements in place and a $3 \times 2$ factorial arrangement of treatments. The repeated measurement in place takes into consideration the common variation on the results coming from the placentome (cotyledon and caruncle from the same cow). The main factors were trimester of gestation (first, second or third) and the side of the placenta (maternal or fetal). Data was analyzed with the Proc Mixed of SAS (9.4). The model contained the side of the placenta, the third of gestation and their interaction as fixed variables. And the cow as random variable. If the value of the interaction side and third of gestation was less than 0.1 the option slice of SAS was used for mean separation. 
Table 2. Primers used in this study .Sequence, annealing temperature and PCR product length.

\begin{tabular}{llll}
\hline Primer & $\mathbf{5} \mathbf{- 3}^{\prime}$ Sequence & $\begin{array}{l}\text { Annealing } \\
\text { temperature }\end{array}$ & $\begin{array}{l}\text { Product } \\
\text { (base pairs) }\end{array}$ \\
\hline FATP-1 FW & AGCCTGGTCAAGTTCTGTTCTGGA & $60^{\circ} \mathrm{C}$ & 142 \\
FATP-1 RV & AGAAGAGTCGATCATCCATGCCCT & & \\
FATP-4 FW & CTACTCAAACAGCGTGGCCAACTT & $60^{\circ} \mathrm{C}$ & 97 \\
FATP-4 RV & ACCCACAAACTCATTGCGGTTCTC & & \multirow{2}{*}{113} \\
FABP-1 FW & CAAGTACCAAGTCCAGACCCAG & $55^{\circ} \mathrm{C}$ & \\
FABP-1 RV & GCACGATTTCCGACACCC & & \multirow{2}{*}{191} \\
ACTB FW & GCCAGGTCATCACCATCGG & $58^{\circ} \mathrm{C}$ & \\
ACTB RV & CAGCACCGTGTTGGCGTAG & & 189 \\
FABP-4 1 FW & ATGAAAGAAGTGGGCGTGGGCTTT & Undetermined \\
FABP-4 1 RV & GCTCTTGACTTTCCTGTCATCTGG & & \multirow{2}{*}{130} \\
FABP-4 2FW & AGATGAAGGTGCTCTGGT and & Undetermined \\
FABP-4 2RV & CTCATAAACTCTGGTGGC & & \\
\hline
\end{tabular}

\section{RESULTS}

FATP-1 mRNA expression shows a side by third of gestation interaction $(\mathrm{P}=0.07$, Figure 1$)$. This interaction is mainly due to a greater FATP-1 mRNA expression during the first third of gestation on the fetal side of the placenta compared with the maternal side $(\mathrm{P}<0.01)$. On the second third of gestation, the expression of fetal FATP-1 mRNA decreases in relationship with the first third and remains greater than the maternal side $(\mathrm{P}<0.05)$. By the last third of gestation there is no difference between the maternal and the fetal FABP-1 mRNA expression $(\mathrm{P}>0.1)$.

There is no effect on FATP-4 (Figure 2) and FABP-1 (Figure 3) mRNA expression due to side (P $>0.05)$, a length of gestation $(\mathrm{P}>0.05)$ or interaction side by length of gestation $(\mathrm{P}>0.1)$.

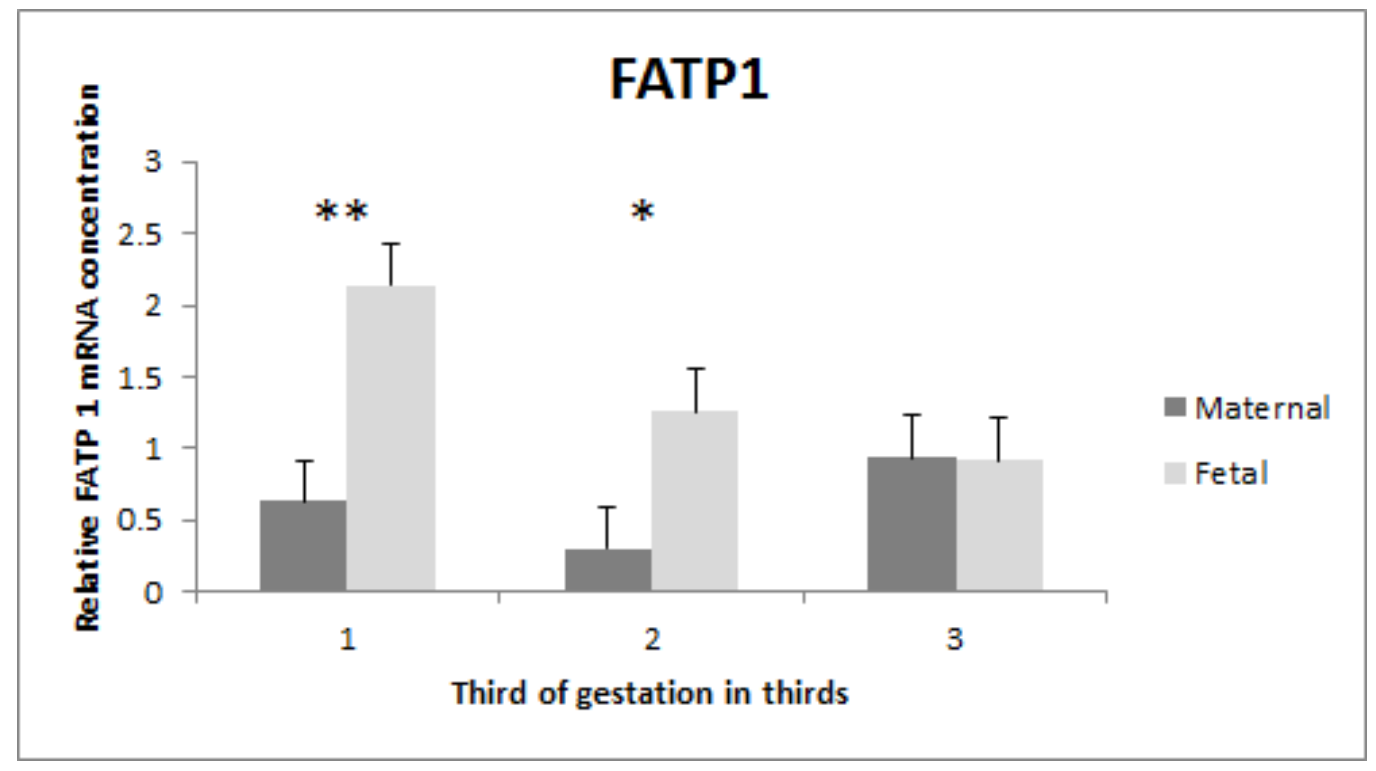

Figure 1. Relative concentration of Fatty acid Transport Protein (FATP) 1 mRNA in caruncle or cotyledon a different thirds of gestation on bovine placenta. Data is presented as LS means and SEM. P value for time of gestation $<0.01$, for site (caruncle or cotyledon) $>0.1$, and for the interaction time by site $=$ 0.07. Slice option of SAS 9.4 was used for mean separation in which $* * \mathrm{P}<0.01 ; * \mathrm{P}<0.05$ 


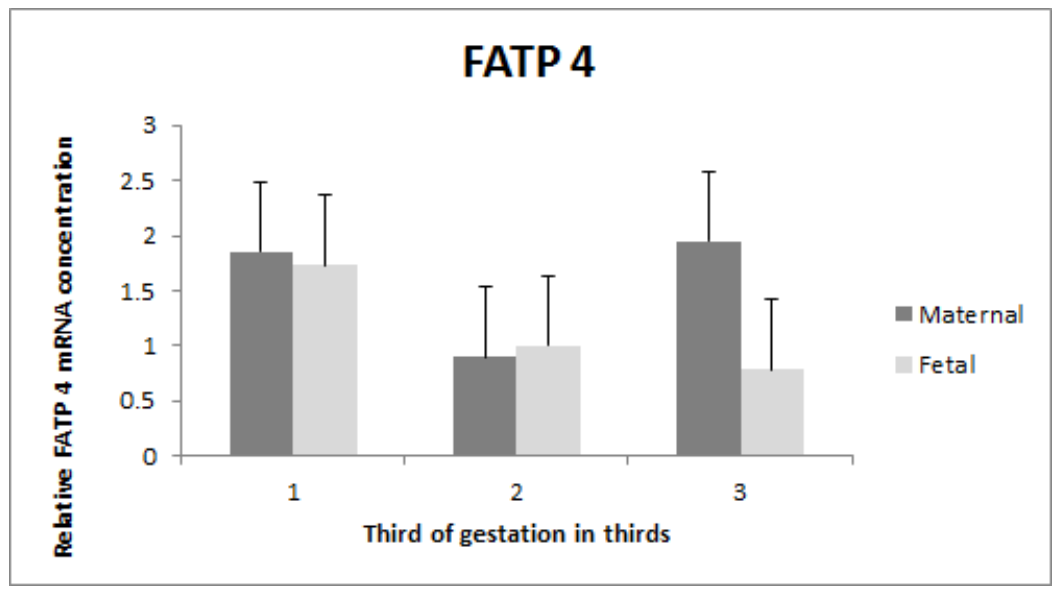

Figure 2. Relative concentration of Fatty acid Transport Protein (FATP) 4 mRNA in caruncle or cotyledon at different thirds of gestation on bovine placenta. Data is presented as LS means and SEM. P value for time of gestation $>0.1$, for site (caruncle or cotyledon) $>0.1$, and for the interaction time by site $>0.1$.

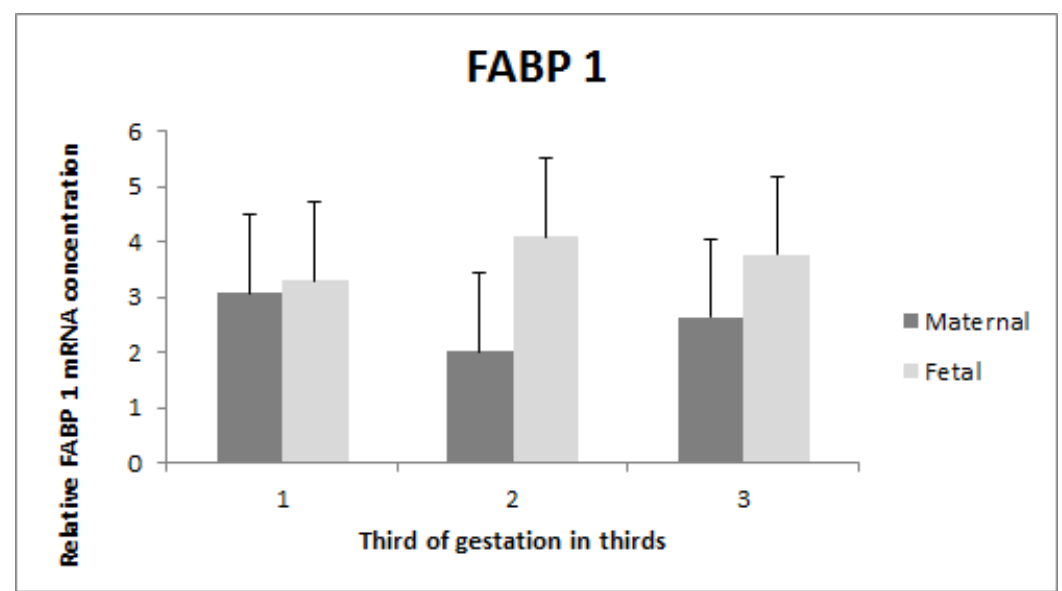

Figure 3. Relative concentration of Fatty acid Binding Protein (FABP) 1mRNA in caruncle or cotyledon at different thirds of gestation on bovine placenta. Data is presented as LS means and SEM. P value for time of gestation $>0.1$, for site (caruncle or cotyledon) $>0.1$, and for the interaction time by site $>$ 0.1 .

\section{DISCUSSION}

As we are aware this is the first publication that shows mRNA expression of FATP-1, FATP-4 and FABP-1 during different stages of gestation and in different parts of the bovine placentome. Changes on mRNA expression of a particular gene is not always associated with changes in protein concentration for that particular gene. However, changes in mRNA expression give a first insight of biological process occurring in the tissue.

It is known that essential fatty acids cannot be synthesize and therefore they are obtained from the diet. During fetal development these fatty acids are provided by the dam from the placental. Some of these fatty acids, such as arachidonic acid (AA) and docosahexaenoic acid (DHA), are very important in the development of the nervous tissue in all mammals (INNIS, 2005); therefore, the passage of these fatty acids through the placenta is a process that may have a controlled regulatory mechanism of action (LAURITZEN et al., 2016). Bell (1995) mentions that the passage of fatty acids through the bovine placenta is low. However, the finding of mRNA of fatty acids transporters and that the expression of them have different patterns during gestation may show that this low passage of fatty acids has a great control. Our results show that there are changes only in FATP-1 expression and not in FATP-4 or FABP-1. This may be due to affinity to specific fatty acid which is important at a particular stage of gestation (first and second third) but not that important in other (last third of gestation). Increase in FABP gene expression was observed in specific tissues that need a particular fatty acid, such as in cold-acclimated ducks (BÉNISTANT, et al., 1998) or in pregnant ewes (ZHU et al., 2010). The affinity of the FABP to the fatty acids depends on 
many factors such as specie, tissue, number of double bond and carbon length of the fatty acids (HANHOFF et al., 2002). In humans, there is a mayor affinity of FABP-1 to essential polyunsaturated fatty acids than to no essential saturated fatty acids. (CAMPBELL et al., 1996; LAURITZEN et al., 2001). However there are no studies in bovine that evaluate the affinity of FABPs and essential fatty acids.

As stated in the materials and methods, with the described setting we were not able to detect FABP-4 mRNA concentration. It is possible that we were not able to find the right conditions or primers, but it is also possible that FABP-4 is not express in bovine placenta.

\section{CONCLUSION}

Only FATP-1 mRNA expression changes in bovine placentome, having a greater expression on the fetal side comparing with the maternal side on early gestation, but the difference decreases in the second half of gestation and are similar at the end of the gestation.

\section{ACKNOWLEDGEMENTS}

This work was partially financially supported by the PICT-2008-00314, Metabolismo de Acidos Grasos en Rumiantes (ANPCyT)

RESUMO: O objetivo do estudo foi avaliar o efeito do tempo de gestação na expressão de mRNA de transportador de ácidos graxos em placenta bovina materna e fetal. Foram colhidas amostras de placentas de 12 vacas em diferentes terços da gestação ( $\mathrm{n}=4$ por terço) no abatedouro para medir a expressão de mRNA de FATP-1, FATP-4, FABP-1 no lado materno (carúnculos) e fetal (cotilédones). Uma vez que a placenta foi removida, $1 \mathrm{~cm} 2 \mathrm{foi}$ dissecado e, dividido em carúnculos e cotilédones, armazenado em tubos estéreis, caiu em nitrogenio líquido e mantido a $-80^{\circ} \mathrm{C}$ até a análise rtPCR. Os dados foram analisados como um delineamento inteiramente casualizado com esquema fatorial $3 \mathrm{x} 2$, utilizando o procedimento misto (SAS 9.3) com medidas repetidas no espaço. O tempo de gestação, o lado da placenta e sua interação foram fatores fixos, enquanto que o animal foi um fator aleatório. Houve um tempo de interação do tratamento $(\mathrm{P}<0,01)$ na expressão de mRNA de FATP-1 devido a uma maior expressão de mRNA em cotilédones no primeiro terço da gestação em comparação com a concentração em carúnculas. No segundo e terceiro terços da gestação, a expressão de mRNA nos cotilédones diminuiu, atingindo uma expressão semelhante à observada em carúnculas. A proteína de transporte de ácidos graxos 4 e a expressão de mRNA de FABP-1 não foram diferentes (P> 0,1). Concluímos que a FATP-1 poderia desempenhar um papel importante no transporte de ácidos graxos durante o desenvolvimento fetal precoce.

PALAVRAS-CHAVE: Proteína de ligação a ácidos graxos. Programação fetal. Acidos graxos.

\section{REFERENCES}

BÉNISTANT, C.; DUCHAMP, C.; COHEN-ADAD, F.; ROUANET, J. L.; BARRÉ, H. Increased in vitro fatty acid supply and cellular transport capacities in cold-acclimated ducklings (Cairina moschata). American Journal of Physiology, v. 275, p. R683-690, 1998.

BELL, A. W. Regulation of organic nutrient metabolism during transition from late pregnancy to early lactation. Journal of Animal Sciences, v. 73, p. 2804-2819, 1995. https://doi.org/10.2527/1995.7392804x

BUSTIN, S. A. Quantification of mRNA using real-time reverse transcription PCR (RT-PCR), trends and problems. Journal of Molecular Endocrinology, v. 29, p. 23-39, 2002. https://doi.org/10.1677/jme.0.0290023

CAMPBELL, F. M.; GORDON, M. J.; DUTTA-ROY, A. K. Preferential uptake of long chain polyunsaturated fatty acids by isolated human placental membranes. Molecular Cell Biochemistry, v. 155, p. 77-83, 1996. https://doi.org/10.1007/BF00714336

HANHOFF, T.; LÜCKE, C.; SPENER, F. Insights into binding of fatty acids by fatty acid binding proteins. Molecular Cell Biochemistry, v. 239, p. 45-54, 2002 https://doi.org/10.1023/A:1020502624234

INNIS, S. M. Essential fatty acid transfer and fetal development. Placenta, v. 26 Suppl A, p. 70-75, 2005. 
LAURITZEN, L.; HANSEN, H. S.; JØRGENSEN, M. H.; MICHAELSEN, K. F. The essentiality of long chain n-3 fatty acids in relation to development and function of the brain and retina. Progress in Lipid Research, v. 40, p. 1-94, 2001. https://doi.org/10.1016/S0163-7827(00)00017-5

LAURITZEN, L.; BRAMBILLA, P.; MAZZOCCHI, A.; HARSLØF, L. B.; CIAPPOLINO, V.; AGOSTONI, C. DHA Effects in Brain Development and Function. Nutrients, v. 8, e. 6, 2016.

LIVAK, K. J.; SCHMITTGEN, T. D. Analysis of Relative Gene Expression Data Using Real-Time Quantitative PCR and the 2-[Delta][Delta]CT Method. Methods, v. 25, p. 402-408, 2001. https://doi.org/10.1006/meth.2001.1262

NICKERSON, J. G.; ALKHATEEB, H.; BENTON, C. R.; LALLY, J.; NICKERSON, J.; HAN, X. X.; WILSON, M. H.; JAIN, S. S.; SNOOK, L. A.; GLATZ, J. F.; CHABOWSKI, A.; LUIKEN, J. J.; BONEN, A. Greater transport efficiencies of the membrane fatty acid transporters FAT/CD36 and FATP4 compared with FABPpm and FATP1 and differential effects on fatty acid esterification and oxidation in rat skeletal muscle. Journal of Biological Chemistry, v. 284, p. 16522-16530, 2009. https://doi.org/10.1074/jbc.M109.004788

ZEMJANIS, R. Diagnostic and therapeutic techniques in Animal Reproduction. 2nd Revised edition: Williams \& Wilkins, 1970. 242 p.

ZHU, M. J.; MA, Y.; LONG, N. M.; DU, M.; FORD, S. P. Maternal obesity markedly increases placental fatty acid transporter expression and fetal blood triglycerides at midgestation in the ewe. American Journal of Physiology, v. 299, p. R1224-1231, 2010. https://doi.org/10.1152/ajpregu.00309.2010 